Dr. E. Herzfeld, field director, which appears in the Times of February 4, says that no discovery like it has ever been made anywhere in western Asia. A magnificent series of sculptures, dating back to the time of Cyrus, has been discovered in the area of the palace burnt by Alexander the Great in 330 B.c. The size alone, without taking into account the technique and the informative detail, is overwhelmingly impressive. One panel, 5-6 ft. high, is no less than 1,000 ft. long. The carvings are as fresh as when executed and show rulers, footmen, horsemen, charioteers, servants and burden-bearers in full equipment-material of the greatest historical value. One panel preserved in peculiarly favourable circumstance still shows the colours of the royal garments. A find of no less importance to the prehistorian is recorded in an account of a stone age village which was found under a low mound within two miles of Persepolis. It is dated at about 4000 B.c. and would appear to be in an excellent state of preservation. The mud-brick walls of the houses still stand to a height of 5-7 ft. and the interior surfaces show mural paintings in red water colour. The polychrome pottery, Dr. Herzfeld reports, exceeds in beauty and age that found in Babylonia, marking "a new chapter in the history of prehistoric art".

\section{International Congress of Ethnological and Anthropological Sciences}

Considerable progress has been made in the discussion of the proposal to institute an international congress of the ethnological and anthropological sciences. Arrangements are now being made for a preliminary conference for further discussion to be held in Basel on April 20-22 next. Invitations to the conference are being issued by the Royal Anthropological Institute of Great Britain, while the local arrangements are in the hands of Dr. Felix Speiser, director of the Museum of Ethnology, Basel. The conference will be welcomed on behalf of the City and the Education Committee, and its sessions will be held in the Burgeratsaal. The subjects for discussion by the conference are the scope of the proposed congress and its relation to existing congresses of like character, such as the International Congress of Americanists and the International Congress of Prehistoric and Protohistoric Sciences; constitution and procedure; and the date and place of the first meeting. On this last point, it has been suggested that meetings should take place in years alternate to those of the Prehistoric and Protohistoric Sciences Congress and coinciding once in every four years with the European meetings of the Americanists' Congress.

\section{Insect-Eating in Siam}

INSECT-EATING habits of monkeys have persisted, and still persist, not only amongst the most primitive races of mankind, like Australian aborigines and the African pygmies, but even in many races which have reached the agricultural stage. An interesting example is offered by the Laos of Siam, whose habits of eating insects and other invertebrates have been recently studied in some detail by $\mathrm{Mr}$. W. S. Bristowe (Trans. Entom. Soc. Lond., 1932). The list of animals used as food by the Laos includes many species and exhibits a great variety, but certain of them are considered as special delicacies. Here belong, for example, giant water-bugs (Lethocerus indicus), measuring about two inches in length and fetching up to $4 d$. a piece on the markets; large spiders, Nephila maculata and Melopoeus albostriatus ('bird-eaters'); eggs of king crab, Tachypleus gigas, which look like caviare, but taste like potato ; larvæ, pupæ and adults of the dung beetles, Oryctes rhinoceros and Helicopris sp.; a large cicada, Dundubia intemerata; etc. There is no reason to think that insect-eating habits of the Laos were acquired owing to the lack of other food, since the Siamese living under the same conditions do not eat insects to such a great extent. On the other hand, it is interesting to note that the Laos are considered to possess greater stamina and to be harder workers than the Siamese; this may be due to the extra protein obtained by the Laos from their animal food. The average diet of a Siamese includes fish as practically the only source of protein; the protein content of fish is 18-23 per cent, and that of roasted spiders is so high as $63 \cdot 4$ per cent.

\section{Fauna of the Swiss National Park}

The area of mountain, forest and valleys comprising the Nature reserve which forms the Swiss National Park is a tract of country that is rigidly preserved. Its fauna and flora are subjected to the minimum of interference on the part of man and for this reason afford many problems of special interest to the biologist. Under the auspices of the commission for the scientific investigation of the Swiss National Park, a series of quarto memoirs on researches undertaken in that area is being published. The sixth memoir in that series has recently come to hand and deals with the forest insects of the Park ("Les Insectes Forestiers du Parc National Suisse". Pp. $50+24$ plates. Aarau : H. R. Sauerländer et Cie. 12 francs). Its author, Dr. Aug. Barbey, mentions that the circumstances in which these insects were studied were purely economic and were in connexion with the ravages they cause among the forest trees. The life-history, mode of life and economic status of the more important species of insects are described. Various stages in their lifecycle, their larval burrows in wood and bark and other phases of these insects are admirably portrayed in the series of plates that accompany this memoir. Their ecological relations are also dealt with whether they be destructive forms, parasites or predators.

\section{Reduction of Chimney Emissions}

THE Technical Committee appointed by the Electricity Commissioners in 1930 to consider the methods that should be taken to prevent the emission of soot, ash and grit from the chimneys of electric power stations has now published its report (London : H.M. Stationery Office, 5s.). A sub-committee made 
a thorough investigation, visiting many foreign stations which have adopted preventive measures. In 46 of the 111 British selected stations no grit extraction plant has yet been installed. The subcommittee regards grading by sieves as unsatisfactory, as it is impossible when the mesh is too small and untrustworthy for larger values. Particles below 20 microns ( 1 micron is a thousandth part of a millimetre) when discharged into an air stream are sufficiently diffused to avoid creating a nuisance. The only satisfactory way of testing the efficiency of dust extraction plant is to weigh the dust in unit volume of the gases at as high a point in the chimney as practicable. In Germany, where the power stations are generally larger than in Great Britain, electrostatic precipitation together with very high chimneys is favoured. The main conclusions arrived at by the Committee are that dust nuisance is avoidable with new stations, but the application of means for its prevention to all existing stations may not be practicable. There is an urgent need for standardisation of good methods of testing dust extraction plant. For pulverised fuel installations the electrostatic precipitator is the most suitable type to use. Water for dust extraction is not to be com. mended. The minimum height of chimneys should be at least two and a half times that of the highest point of the generator station buildings. Photographs are given of the filters used for separating ash and grit particles and of plant for multiplecyclone dust extraction.

\section{Gaseous Tubes for Lighting}

THe study of the discharge of electricity through gases has led to many important practical developments, the latest being the invention of vacuum tubes for lighting. If discharge tubes are filled to the same gaseous pressure with different gases such as helium, neon, argon, hydrogen and nitrogen, it is found that a certain definite voltage must be applied to the terminals of the tube before luminous effects are produced. This voltage depends on the nature of the gas and the pressure in the tube. In general, neon produces a luminous effect at lower voltages than the other gases and then comes helium. In some cases a mixture of gases becomes luminous at a lower voltage than any of the pure gases forming it. In a lecture to the Preston Scientific Society given on December 2, 1932, J. N. Addington gave an interesting account of the progress made in developing gaseous tubes for lighting and signalling purposes. In an Osglim lamp, which takes only a small fraction of the power taken by a flament lamp, the electrodes are of nickel or iron placed about $2 \mathrm{~mm}$. apart and the neon gas filling has a definite low pressure. At 160 volts the lamp becomes luminous. These lamps operate from alternating current mains. Neon valves which operate traffic signal devices have now been developed at the Prestonlampworks of Messrs. Siemens Brothers and $\mathrm{Co}$. The red neon signs which are now familiar to all dwellers in cities have iron or nickel electrodes and the illumination is produced from the positive column. The intensity of illumina- tion per unit area is relatively low in these lamps, which are called cold cathode tubes. In 'hot cathode tubes' currents nearly a hundred times as great can be obtained. The electrodes are coated with mixtures of alkaline earths and have a very high electronic emission when heated to $1,200^{\circ} \mathrm{C}$. The use of metallic vapours like sodium, cadmium and magnesium has still further increased the efficiency of these tubes, but the colours at present obtained leave much to be desired when compared with daylight.

\section{Gifts to Science}

Sir Dugald Clerk, who died on November 12 (see NATURE of December 24, p. 953), bequeathed $\mathfrak{1 3 , 0 0 0}$ to the Institution of Civil Engineers ; $£ 2,000$ to the Royal Society ; $£ 1,000$ to the Royal Institution; $£ 1,000$ to the Royal Society of Arts; $£ 1,000$ to the Institution of Mechanical Engineers; $£ 1,000$ to the University of Glasgow; $£ 1,000$ to the University of Leeds; $\mathfrak{f 1 , 0 0 0}$ to the University of St. Andrews ; $£ 1,000$ to the University of Manchester; $£ 1,000$ to the University of Liverpool. The residue of the property is to be divided into thirty-one parts ; three of these parts are to go to the Institution of Civil Engineers; two to the Royal Society; one to the Royal Institution; one to the Royal Society of Arts ; one to the Institution of Mechanical Engineers ; and one each to the Universities of Glasgow, Leeds, St. Andrews, Manchester, and Liverpool.

\section{Entomological Society of London}

THe Entomological Society of London will celebrate its hundredth anniversary on May 3, and a preliminary programme of the centenary celebrations on May 3-4 has recently been published. On May 3, a general meeting will be held in the rooms of the Royal Geographical Society at 3 P.M. and a scientific conversazione at 8.30 P.M. A reception has been arranged for May 4 at 9.30 P.M. This will be held at Lancaster House, St. James's, S.W.I, when the Right Hon. Walter Elliot, Minister of Agriculture and Fisheries, will receive the guests. Further information can be obtained from the Secretary, 41 Queen's Gate, London, S.W.7.

\section{Chadwick Public Lectures}

THe next series of Chadwick Public Lectures begins on February 21, with a discourse on "The Hippocratic Tradition" by Dr. Matthew B. Ray. The lecture will be given in the hall of the Royal Society of Tropical Medicine, 26 Portland Place, W.1, at 5.15. The second lecture will be given by Dr. E. Killick Millard on "Housing", on March 9 at 8 P.M. at the Royal Sanitary Institute. How to secure a pure milk supply is the question chosen by Dr. J. Walter Carr, for his lecture- "Cows' Milk" in March at the Royal Society of Tropical Medicine. In it, he will discuss the relative benefits of human and bovine milk for infants, the value of milk in adult life and how to render cows' milk a safe food. In May, Mr. P. W. Coombe will lecture on "Port of London Sanitary Administration". The actual processes and details of the organisation and maintenance of port and river hygiene will be discussed. Another lecture 